\title{
Erken Erişkinlik Döneminde Serum Ferritin ve C-Reaktif Protein Düzeylerinin Polikistik Over Sendromu Etyopatogenezine ve İlişkili Klinik Durumlara Etkisi
}

\author{
Serum Ferritin And C-Reactive Protein Levels In The Etiopathogenesis of Polycystic Ovary Syndrome \\ And Its' Related Conditions Among Early Adulthood Females
}

\section{Esra Nur TOLA ${ }^{1}$, Hilmi Baha ORAL ${ }^{1}$}

1. Süleyman Demirel Üniversitesi Tıp Fakültesi, Kadın Hastalıkları ve Doğum Anabilim Dalı, Isparta, Türkiye

\section{$\ddot{O Z Z E T}$}

Amaç: Serum ferritin ve C-reaktif protein (CRP) düzeylerinin polikistik over sendromu (PKOS) etyopatogenezindeki yerini ve $P K O S$ 'un uzun dönem morbiditelerinden olan kardiyovaskuler hastalık (KVH) ve insulin rezistansı (IR) gelişimi riskiyle ilişkisini araştırmaktır.

Gereçler ve Yöntem: 68 PKOS ve 57 kontrol grubu olmak üzere toplam 125 hasta prospektif olarak çalıșaya dahil edildi. Tüm hastaların hormon değerleri, biyokimyasal parametreleri, ferritin ve CRP düzeyleri ölçüldü ve antropometrik ölçümler kaydedildi. Vücut kitle indeksi (VKI) $\geq 25 \mathrm{~kg} / \mathrm{m} 2$ olmast obezite, bel kalça oranı $(W H R) \geq 0.80$ olması abdominal obezite olarak tanimlandi. 'Homeostasis model assessment of IR index' (HO$M A-I R)$ düzeyinin $>3.16$ olması IR olarak tanımlandı. Belirtilen kriterlerden en az ikisine sahip olan hastalarda KVH ge-

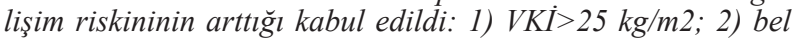
çevresi $\geq 80 \mathrm{~cm}$; 3) IR; 4) Dislipidemi.

Bulgular: VKI, WHR, Ferriman Gallway skoru (FGS), dehidroepiandrostenodion-sülfat, açlık kan şekeri, insulin, $\mathrm{HO}$ MA-IR indeksi PKOS grubunda kontrol grubuna göre daha yüksekti. HDL kolesterol PKOS grubunda kontrol grubuna göre daha düsükken; trigliserid, LDL kolesterol ve total kolesterol seviyeleri gruplar arasinda benzerdi. Serum ferritin ve CRP düzeyleri açısından PKOS ve kontrol grubu arasinda anlaml fark izlenmedi. Ferritin düzeyinin yas, VKI, WHR ve FGS skorları ile ilişkisi bulunmazken; CRP VKI ile pozitif koreleydi. Araştırdığımı parametrelerin biyokimyasal parametreler ve bazal hormon düzeyleriyle ilişkisi bulunmadl. Ferritin düzeyinin KVH gelişim riski için prediktif etkisi bulunmazken; CRP düzeyi KVH gelisim riskini öngörmede hem tüm çalışma grubu içinde hem de PKOS grubu içinde pozitif prediktif değere sahipti. IR gelisiminde ise serum CRP ve ferritin düzeyi ne tüm grupta ne de PKOS grubu içinde prediktif değere sahipti. Obezitenin etkisi dişlandiktan sonra ise IR gelişiminde sadece abdominal obezite pozitif prediktif etkiye sahipti.

Sonuç: Erken eriskinlik döneminde serum ferritin ve CRP düzeylerinin PKOS gelişiminde etkisi görünmemektedir. Artmış CRP düzeyleri hem PKOS grubunda hem genel populasyonda KVH gelişim riskini öngörmede bir belirteç olabilir.

Anahtar Kelimeler: ferritin, C-reaktif protein, polikistik over sendromu

\section{ABSTRACT}

Objective: We aimed to evaluate serum ferritin and $C$-reactive protein (CRP) levels in early adulthood females with polycystic ovary syndrome (PCOS) to determine their roles in the etiopathogenesis of PCOS and clinical implications, including cardiovascular disease (CVD) and insulin resistance (IR), related to PCOS.

\section{Iletişim Bilgileri}

Sorumlu Yazar: Dr. Esra Nur TOLA

Yazışma Adresi: Süleyman Demirel Üniversitesi Tıp Fakültesi, Kadın Hastalıkları ve Doğ. Anabilim Dalı, Isparta, Türkiye E-posta: perinatalog@hotmail.com

Tel: +90 (246) 2119241 Gsm: +90 (532) 7921084

Makale Geliş Tarihi: 27.02.2018

Makale Kabul Tarihi: 07.03.2018

DOI: http://dx.doi.org/10.16948/zktipb.399436
Material and Methods: A total of 125 participants, 68 PCOS and 57 control, were recruited prospectively for our study. Basal hormone levels, biochemical parameters, and serum ferritin and $C$-reactive protein levels, were assessed and antropometric measurements were recorded. Body mass index (BMI) $\geq 25 \mathrm{~kg} /$ $m 2$ were accepted as obesity and waist-to-hip ratio (WHR $) \geq 0.80$ was defined as abdominal obesity. IR was determined when the homeostasis model assessment of IR index (HOMA-IR) more than 3.16. CVD risk was accepted as the presence of at least two out of the criteria: 1. BMI> $25 \mathrm{~kg} / \mathrm{m} 2,2$. Waist circumferen$c e \geq 80 \mathrm{~cm}, 3 . \mathrm{IR}$, and 4. Dyslipidemia.

Results: BMI, WHR, Ferriman-Gallway scores, dehidroepiandrostendion sulphat, glucose, and HDL cholesterol was significantly decreased in PCOS group whereas trygliceride, $L D L$ cholesterol and total cholesterol levels were distributed homogenously between groups. We could not found any difference in terms of serum ferritin and CRP levels between PCOS and control groups. Serum ferritin wasn't correlated to age, $B M I, W H R$, and FGS, whereas, CRP was positively correlated with BMI. There wasn't any association between investigated markers and biochemical parameters, and basal hormone levels. Any predictive effect of serum ferritin on the development of CVD risk was found among PCOS group and whole group. Serum CRP levels had positive predictive effect for the development of CVD among PCOS group and whole group. None of investigated markers were predictive for IR among POCS group and whole group even after adjustment for obesity and abdominal obesity.

Conclusion: It seems to be any role of serum ferritin and CRP levels in the etiopathogenesis of PCOS in early adulthood period. Elevated CRP levels could be a predictive marker for the development of CVD risk among PCOS patients and whole group.

Keywords: ferritin, C-reactive protein, polycystic ovary syndrome

\section{GíRIŞ}

Polikistik over sendromu (PKOS) reproduktif dönemdeki kadınlarda sık görülen, kozmetik ve reproduktif sonuçları olan bir endokrinopatidir ve sıklıkla menstrual düzensizlik ve hiperandrojenemi ile prezente olur (1). Uzun dönemde obezite, insülin rezistans1 (IR), Tip 2 diabet, metabolik sendrom ve kardiyovaskuler hastalık (KVH) gibi morbiditelerle ilişkilidir (2). Patofizyolojisi net aydınlatılamasa da PKOS'un hem klinik olarak ortaya çıkması hem de uzun dönem morbiditelerinin oluşumunda oksidatif stres (OS) ve kronik düşük dereceli inflamasyonun rolu olduğu düşünülmektedir $(3,4)$.

Ferritin demir homeostazisinde önemli görevleri olan, hücrede demir depolayan intraselüler bir proteindir ve serum ferritin seviyeleri s1klıkla vücut demir durumunu tahmin etmek için kullanılır (5). 
Demirin güçlü oksidan özellikleri olup artmış demir seviyeleri pek çok hastalığın gelişiminden sorumlu olan OS ile ilişskilendirilmiştir. Serbest demir çok toksiktir ve Fenton reaksiyonuna katılarak OS'e katkıda bulunur (6). Demirin katalizlediği OS'in over dokusu ve granuloza hücre fonksiyonu üzerine zararlı etkisi olabilir (7). Ferritin ayn zamanda bir akut faz reaktanı olup inflamasyon durumunda artar ve metabolik sendrom, Tip 2 diabet ve PKOS gibi inflamasyonun suçlandığı süreçlerde yüksek seviyelerde bulunmuştur (8). Demir metabolizması kronik inflamasyon ve OS tarafindan etkilenir (9). İnflamatuar sitokinler hücre yüzeyinde transferrin reseptörlerini artırarak dokuda demir depozisyonlarına neden olur (10). Hafif artmış demir depolarının glikoz metabolizması bozuklukları (IR ve Tip 2 diabet vb), obezite ve metabolik bozukluklara neden olduğuyla da ilgili çalışmalar vardır $(8,11,12)$ ve bunun muhtemel mekanizmasının demirin promote ettiği OS'e bağlı doku ve organ hasarı olduğu düşünülmektedir (7). Demir fazlalığı diabet ve IR'nın patofizyolojik rol oynadığ 1 hastalıklarda önemlidir ve demirin azaltılması diabeti ve IR'nin neden olduğu patolojik durumları önler ve tedavi eder (6). Abdominal obezite ve IR, PKOS etyopatogenezine katkıda bulunan major etmenlerdendir (13), bu da demir fazlalığının PKOS gelişimiyle IR yoluyla da ilgili olabileceğini düşündürür.

Akut faz reaktanlarından olan C-reaktif protein (CRP) düzeyinin Tip 2 diabet, hiperinsülinemi ve PKOS gibi inflamatuar süreçlerde yüksek olduğu gösterilmiştir (14). Serum CRP düzeyinin obez PKOS'lu hastalarda nonobez PKOS'lara göre daha yüksek olduğu ve hem obezlerde hem nonobezlerde 6 ay metformin tedavisiyle seviyelerinin düştüğü izlenmiştir (15). Yapılan çalışmalarda ayrıca ferritin, CRP gibi inflamasyonun akut faz reaktanlarının KVH'larda da arttığı gösterilmiştir (16).

PKOS etyopatogenezinde ve uzun dönem morbiditelerinin oluşumunda kronik inflamasyonun ve OS'nin etkisinin bilinmesi, ferritinin hem OS ve inflamasyon belirteci hem de PKOS oluşumuna katkıda bulunan IR gelişiminde rolunun anlaşılmas1, serum ferritin düzeyi ölçümünün vücutta demir yüklenmesini göstermede kolay, ucuz, standardize ve ulaşılabilir bir test olması ve CRP'nin de akut faz reaktanı olmasından yola çıkarak; çalışmamızda erken erișkinlik döneminde olan kadınlarda serum ferritin ve CRP düzeyinin PKOS etyopatogenezindeki rolünü ve antropometrik, biyokimyasal ve hormonal parametreler ile ilişkisini ortaya koymayı amaçladık. Çalışmamızda aynı zamanda serum ferritin ve CRP düzeyinin IR ve KVH gibi PKOS'un uzun dönem morbiditelerinin gelişmesinde potansiyel rollerini araştırmayı da planladık.

\section{GEREÇ ve YÖNTEM}

Çalışmamız Süleyman Demirel Üniversitesi (SDÜ) Tıp Fakültesi Kadın Hastalıkları ve Doğum Polikliniğine başvuran 15-23 yaş arası genç hastalar üzerinde Ekim 2017 ve Şubat 2018 tarihleri arasında prospektif olarak planlandı. Çalışmamıza revize
Rotterdam kriterlerine göre PKOS tanısı konmuş 68 hasta (PKOS grubu) ve ovulatuar siklusları olan 57 hasta (kontrol grubu) olmak üzere toplam 125 hasta katıldı. Hastalardan çalışmaya başlamadan önce yazılı onam alındı. Çalışmamız SDÜ Etik Kurulu tarafindan 72867572.050.01.04-195060 protokol numarası ile onayland1.

\section{Hasta seçimi}

Belirtilen kriterlerden en az ikisine sahip olan hastalar PKOS olarak kabul edildi. 1) Oligomenore ( $>35$ gün uzun ya da $<8-10 /$ yıl az siklus varlığ 1 ) veya amenore (ilaç olmadan adet göremeyen); 2) fenotipik (Ferriman-Gallway skoru (FGS) $>8$ ) veya biyokimyasal (serbest testosteron $>3.6 \mathrm{ng} / \mathrm{ml}$ ve/veya dehidroepiandrostenedion sülfat (DHEA-S) $>9.7$ $\mu \mathrm{mol} / \mathrm{l})$ hiperandrojenemi (17); 3) polikistik over varlığ (ultrasonda overyan hacim $>10 \mathrm{~cm} 3$ ve çap1 2-9 $\mathrm{mm}$ arası $\geq 12$ folikul varlığ $)$.

Kontrol grubu normal overyan morfolojiye sahip, düzenli ovulatuar menstrual siklusları olan (serum progesteron seviyesi siklusun 21. gününde $>5 \mathrm{ng} /$ $\mathrm{ml}$, siklus uzunluğu 21-35 gün) ve benign jinekolojik nedenler ile polikliniğimize başvurmuş hastalardan oluşmaktaydı. Kontrol grubundaki hastaların serum androjen seviyeleri de normal aralıkta idi.

Hiperandrojeneminin sekonder nedenleri (konjenital adrenal hiperplazi, androjen üreten tümör, Cushing sendromu vb), endokrinopatiler (tiroid hormon bozuklukları, hiperprolaktinemi), sistemik hastalıklar (hipertansiyon, diabet, KVH), otoimmun hastalıklar, kanser, hemokromatozis, insülin sekresyonu veya lipoprotein metabolizmasinı veya hipotalomo-hipofizo-overyan aksı değiştiren ilaç kullanımı olanlar, oral kontraseptif veya antiinflamatuar ilaç kullananlar ve sigara-alkol kullanımı olan vakalar çalışmadan dışlandı. Katılımcılar en az 3 yıldır siklus gören ve son 6 ay içinde kan transfüzyonu almamış kişilerden oluşmaktaydı.

\section{Bazal değerlendirme ve antropometrik ölçümler} Tüm hastalar bazal hormon değerleri ve overyan morfolojik özellikleri açısından siklusun 3. günü kan örneği ve pelvik ultrason ile değerlendirildi. Hastaların vücut kitle indeksi (VKİ), bel çevresi (WC), kalça çevresi (HC), bel kalça oranı (WHR) ve FGS skorlar1 kaydedildi. VKI $\geq 25 \mathrm{~kg} / \mathrm{m} 2$ olan hastalar obez olarak tanımlandı. Bel çevresi son kaburga ile iliak krest arasındaki en geniş çaptan ve kalça çevresi büyük femoral trokanterler arası en geniş çaptan ölçüldü. WHR $\geq 0.80$ olması abdominal obezite olarak tanımlandı.

\section{Laboratuar incelemeleri}

Tüm hastalardan siklusun 3. günü 12 saatlik açlık sonrası alınan venöz kan örnekleri 3000 rpm'de 10 dakika santrifuj edildi. Kan örneği, eğer serum progesteron $>2 \mathrm{ng} / \mathrm{ml}$ veya östradiol $>150 \mathrm{pg} / \mathrm{ml}$ ise gecikmiş ovulasyonu dışlamak için atıldı. Folikul stimulan hormon (FSH), luteinizan hormon (LH), östradiol, progesteron, DHEA-S, serbest testesteron düzeylerini içeren bazal hormon seviyeleri ve trigliserid (TG), total kolesterol, yüksek dansite- 
li lipoprotein (HDL), düşük dansiteli lipoprotein (LDL), açlık kan şekeri (AKŞ) ve insülin düzeylerini içeren biyokimyasal analiz hemen yapılırken kalan serum, ferritin ve CRP analizine kadar $-80^{\circ} \mathrm{C}$ 'de sakland1.

Serum ferritin seviyesi biyokimyasal otoanalizörde (TBA-2000FR; Toshiba Medical Systems Cooperation, Japan) ve CRP seviyesi BN II System (Siemens, Erlangen, Germany) kullanan nefelometrik metodla ölçüldü.

'AKŞ $(\mu \mathrm{mol} / \mathrm{l})$ x Açlık insülin $(\mathrm{mU} / \mathrm{ml}) / 22.5$ ' formülüyle hesaplanan 'Homeostasis model assessment of IR index' (HOMA-IR) düzeyinin $>3.16$ olması IR olarak tanımland.

Amerikan Klinik Endokrinolojistler Cemiyetinin guideline'a göre belirtilen kritelerden en az ikisine sahip olan hastalarda KVH gelişim riskininin artt1ğ kabul edildi: 1) VKI $>25 \mathrm{~kg} / \mathrm{m} 2,2) \mathrm{WC} \geq 80 \mathrm{~cm}$, 3) IR ve 4) Dislipidemi. Dislipidemi LDL $\geq 110 \mathrm{mg} /$ $\mathrm{dl}, \mathrm{HDL}<35 \mathrm{mg} / \mathrm{dl}, \mathrm{TG} \geq 150 \mathrm{mg} / \mathrm{dl}$, ve total kolesterol $>170 \mathrm{mg} / \mathrm{dl}$ kriterlerinden en az 1 kriterin varlığ 1 olarak kabul edildi (18).

\section{İstatistiksel analiz}

Veriler 'SPSS version 20.0 statistical program' kullanılarak analiz edildi. $\mathrm{p}$ değerinin $<0.05$ olması istatistiksel olarak anlamlı kabul edildi. Devamlı değişkenlerin dağılımı Kolmogorov-Smirnov testi ile analiz edildi ve karşılaştırılmasında Student-t test ve Mann-Whitney U testi kullanıldı. Sonuçlar ortalama \pm standart deviasyon (SD) olarak verildi. Serum ferritin ve CRP düzeyinin PKOS ile ilişsili klinik durumların gelişmesindeki prediktif değerini saptamak için multivariat lojistik regresyon analizi kullanıldı. Klinik, biyokimyasal ve hormonal parametrelerin ferritin ve CRP ile ilişkisini bulmak için korelasyon analizi kullanıldı.

\section{BULGULAR}

Çalışmamıza revize Rotterdam kriterlerine göre PKOS tanısı konmuş 68 hasta ve normal ovulatuar siklusları olan 57 hasta olmak üzere toplam 125 hasta alınd.

Gruplar arası bazal karakteristik özellikler ve ferritin ve CRP düzeyleri

PKOS grubunun ortalama yaşı $18.87 \pm 2.49$ yıl, kontrol grubunun ortalama yaş1 $19.56 \pm 2.47$ y1l idi. Her iki grup yaş, ortalama menarş yaşı ve siklusun 3. günü bakılan bazal hormon değerleri aç1sından homojen olarak dağılmıştı. VKİ, WHR ve FGS PKOS grubunda kontrol grubuna göre anlamlı olarak daha yüksekti $(\mathrm{p}=0.002, \mathrm{p}<0.0001$ ve $\mathrm{p}<0.0001$, sirayla). DHEA-S seviyeleri de PKOS grubunda $(365.84 \pm 164.55 \mathrm{Ug} / \mathrm{dl})$ kontrol grubuna $(248.56 \pm 120.3 \mathrm{Ug} / \mathrm{dl})$ göre daha yüksek $(\mathrm{p}<0.0001)$ iken serbest testesteron seviyeleri açısından iki grup arasinda fark saptanmadi.

Biyokimyasal parametreler açısından AKŞ, insulin ve HOMA-IR indeksi PKOS grubunda kontrol grubuna göre anlamlı yüksek bulunurken ( $\mathrm{p}=0.02$, $\mathrm{p}<0.0001$ ve $\mathrm{p}<0.0001$, sirayla); HDL kolesterol seviyesi PKOS grubunda $(58.69 \pm 11.30 \mathrm{mg} / \mathrm{dl})$ kontrol grubuna göre $(66.67 \pm 8.94 \mathrm{mg} / \mathrm{dl})$ anlamlı düşük saptand $1(p<0.0001)$. TG, LDL ve total kolesterol seviyeleri açısından iki grup homojen olarak dağılmiştı.

Aneminin ferritin düzeyini azaltıcı etkisi olabileceğinden çalışma gruplarımız arası hemoglobin değerlerini de karşılaştırdık. Hemoglobin düzeyi PKOS grubunda $14.1 \pm 1.4 \mathrm{~g} / \mathrm{dl}$, kontrol grubunda ise $13.1 \pm 1.2 \mathrm{~g} / \mathrm{dl}$ idi. Her iki grup arasında hemoglobin düzeyleri açısından anlamlı fark izlenmedi $(p=0.5)$. Araştırdığımız parametrelerden serum ferritin düzeyleri PKOS grubunda $24.53 \pm 15.39 \mathrm{ng} / \mathrm{ml}$ iken kontrol grubunda $25.98 \pm 19.13 \mathrm{ng} / \mathrm{ml}$ idi. Serum CRP seviyeleri ise kontrol grubunda $2.72 \pm 1.99$ $\mathrm{mg} / \mathrm{dl}$ ve PKOS grubunda $3.35 \pm 3.44 \mathrm{mg} / \mathrm{dl}$ düzeylerinde idi. Serum ferritin ve CRP seviyeleri açısından iki grup arasında anlamlı fark izlenmedi. Gruplar arası bazal karakteristik özellikler ve ferritin ve CRP düzeyleri Tablo 1'de gösterilmiştir.

Tablo 1: Gruplar arası bazal karakteristik özellikler ve ferritin ve CRP düzeyleri.

\begin{tabular}{|c|c|c|c|}
\hline & $\begin{array}{c}\text { Kontrol grubu } \\
(n=57)\end{array}$ & $\begin{array}{l}\text { PKOS grubu } \\
(n=68)\end{array}$ & $p$ değeri \\
\hline Yaş (yıl) & $19.56 \pm 2.479$ & $18.87 \pm 2.49$ & $0.12^{\mathrm{a}}$ \\
\hline VKi $\left(\mathrm{kg} / \mathrm{m}^{2}\right)$ & $22.12 \pm 3.45$ & $24.26 \pm 4.05$ & $0.002^{a}$ \\
\hline WHR & $0.75 \pm 0.06$ & $0.80 \pm 0.07$ & $<0.0001^{a}$ \\
\hline Menarş yaşı & $12.91 \pm 1.13$ & $12.88 \pm 1.37$ & $0.89^{b}$ \\
\hline FGS & $5.54 \pm 3.78$ & $11.56 \pm 5.81$ & $<0.0001^{a}$ \\
\hline \multicolumn{4}{|l|}{ Bazal hormonlar } \\
\hline $\mathrm{FSH}(\mathrm{mlU} / \mathrm{ml})$ & $6.67 \pm 1.74$ & $6.35 \pm 1.92$ & $0.34^{\mathrm{a}}$ \\
\hline LH (mIU/ml) & $7.35 \pm 5.38$ & $8.41 \pm 5.87$ & $0.3^{\mathrm{a}}$ \\
\hline FSH/LH & $1.28 \pm 0.83$ & $1.27 \pm 1.86$ & $0.9^{\mathrm{a}}$ \\
\hline Estradiol (pg/ml) & $31.59 \pm 15.36$ & $34.09 \pm 18.09$ & $0.4^{\mathrm{a}}$ \\
\hline DHEA-S (Ug/dl) & $248.56 \pm 120.30$ & $365.84 \pm 164.55$ & $<0.0001^{b}$ \\
\hline $\begin{array}{l}\text { Serbest testesteron } \\
(\mathrm{pg} / \mathrm{ml})\end{array}$ & $1.56 \pm 0.72$ & $1.85 \pm 1.02$ & $0.08^{\mathrm{a}}$ \\
\hline AKŞ (mg/dl) & $86.41 \pm 9.13$ & $89.56 \pm 5.60$ & $0.02^{\mathrm{b}}$ \\
\hline İnsülin $(\mu \mathrm{U} / \mathrm{ml})$ & $7.39 \pm 3.53$ & $15.22 \pm 10.06$ & $<0.0001^{a}$ \\
\hline HOMA-IR & $1.59 \pm 0.81$ & $3.39 \pm 2.26$ & $<0.0001^{b}$ \\
\hline TG (mg/dl) & $93.04 \pm 45.18$ & $92.16 \pm 39.88$ & $0.9^{\mathrm{a}}$ \\
\hline HDL (mg/dl) & $66.67 \pm 8.94$ & $58.69 \pm 11.30$ & $<0.0001^{b}$ \\
\hline LDL (mg/dl) & $76.81 \pm 35.54$ & $79.60 \pm 35.08$ & $0.6^{\mathrm{a}}$ \\
\hline $\begin{array}{l}\text { Total kolesterol } \\
\text { (mg/dl) }\end{array}$ & $161.68 \pm 38.57$ & $154.81 \pm 33.15$ & $0.2^{\mathrm{a}}$ \\
\hline $\mathrm{Hb}(\mathrm{g} / \mathrm{dl})$ & $13.1 \pm 1.2$ & $14.1 \pm 1.4$ & $0.5^{\mathrm{a}}$ \\
\hline Ferritin (ng/ml) & $25.98 \pm 19.13$ & $24.53 \pm 15.39$ & $0.6^{b}$ \\
\hline CRP (mg/dl) & $2.72 \pm 1.99$ & $3.35 \pm 3.44$ & $0.2^{\mathrm{a}}$ \\
\hline
\end{tabular}

PKOS: Polikistik over sendromu; VKi: Vücut kitle indeksi; WHR: Bel kalça oranı; FGS: Ferriman-Gallway skoru; FSH: Folikul stimulan hormon; LH: Luteinizan hormon; DHEA-S: Dehidroepiandrostenedion sülfat; AKŞ: Açlık kan şekeri; HOMA-IR: Homeostasis model assessment of insulin resistance; TG: Trigliserid; HDL: Yüksek dansiteli lipoprotein; LDL: Düşük dansiteli lipoprotein; Hb: Hemoglobin; CRP: C-reaktif protein.

a İstatistiksel karşılaştırmalar Student-t test ile yapılmıştır b İstatistiksel karşılaştırmalar Mann-Whitney U testi ile yapılmıştır. 
Serum ferritin ve CRP düzeyinin antropometrik, hormonal ve biokimyasal parametreler ile ilişkisi

Araştırılan parametrelerin antropometrik ölçümler ve hirsutizm derecesi ile ilişkisine bakıldığında serum ferritin düzeyinin yaş, VKİ, WHR ve FGS skorları ile ilişkisi bulunmazken serum CRP düzeyleri VKİ ile pozitif korele olarak bulundu $(\mathrm{p}<0.0001$, $\mathrm{r}=0.37$ ).

Biyokimyasal parametreler (AKȘ, insulin, HOMA-IR, TG, HDL, LDL, total kolesterol) ve bazal hormon düzeyleri (FSH, LH, östradiol, serbest testesteron, DHEA-S) ile serum CRP ve ferritin düzeylerinin arasinda korelasyon bulunmadi $(\mathrm{p}>0.05)$. Araştırılan belirteçler ile antropometrik, hormonal ve biokimyasal parametrelerin korelasyonu Tablo 2'de gösterilmiştir.

Serum ferritin ve CRP düzeyinin PKOS ile ilişkili klinik durumlarla ilişkisi

\section{Kardiyovaskuler hastalık}

Serum ferritin ve CRP düzeyinin hem PKOS grubu içinde hem tüm hasta grubu içinde KVH gelişim riski için prediktif etkisine bakıldığında serum ferritin düzeyinin $\mathrm{KVH}$ gelişim riski için prediktif etkisi bulunmazken serum CRP düzeyi KVH gelişim riskini öngörmede hem tüm çalışma grubu içinde $[\mathrm{p}=0.002, \beta=0.26$, OR $(\% 95 \mathrm{CI})=1.30(1.10-1.54)]$ hem de PKOS grubu içinde $[\mathrm{p}=0.03, \beta=0.23$, OR $(\% 95 \mathrm{CI})=1.26(1.02-1.56)]$ pozitif prediktif değere sahipti (Tablo 3).

\section{İnsülin direnci}

Serum ferritin ve CRP düzeylerinin IR gelişimi üzerine etkisine bakıldığında ne tüm çalışma grubu içinde ne de POS grubu içinde araştırdığımız parametrelerin hiçbiri IR gelişimi için prediktif değere sahipti (Tablo 4).

Lojistik regresyon analizinde obezite ve abdominal obeziteye göre düzeltme yapıldıktan sonra ise tüm hasta grubunda abdominal obezite IR gelişimi için pozitif prediktif etkiye sahipti $[\mathrm{p}=0.01, \beta=1.1$, OR $(\% 95 \mathrm{CI})=0.3(0.14-0.78)]$. Serum ferritin ve CRP düzeylerinin ise obezite ve abdominal obezitenin etkisi çıktıktan sonra da IR gelişimi üzerine prediktif etkisi izlenmedi (Tablo 5).

\section{TARTIŞMA}

Vücudun demir durumunu göstermede kullanılan, intraselüler bir protein olan ferritin hem inflamasyonun hem de OS'nin önemli belirteçlerinden bir tanesidir, hatta inflamatuar durumlarda demir eksikliği olsa bile serum ferritini yükselebilir (5, 8). Ferritin aynı zamanda hafif artmış seviyelerinde bile glikoz metabolizmasında bozukluklara yol açar (8). CRP de akut faz reaktanlarından biri olup inflamatuar durumlarda serum seviyesi yükselir (14). İnflamasyon, OS ve IR'nin PKOS etyopatogenezindeki rolu yıllardır pek çok çalışma ile araştırılmış ve PKOS'un hem etyopatogenezinde hem de uzun dönem morbiditelerinin oluşmasında suçlanmıştır $(3,4,19)$. Buradan yola çıkarak serum ferritin ve CRP düzeylerinin PKOS gelişimindeki rolünü

Tablo 2: Serum ferritin ve CRP düzeylerinin antropometrik, hormonal ve biokimyasal parametreler ile ilişkisi.

\begin{tabular}{|c|c|c|c|c|c|c|c|c|c|c|c|c|c|c|c|c|c|}
\hline & & Yaş & Vki & WHR & FGS & AKŞ & $\begin{array}{c}\text { İnsü- } \\
\text { lin }\end{array}$ & $\begin{array}{c}\text { HOMA- } \\
\text { IR }\end{array}$ & TG & HDL & LDL & $\begin{array}{c}\text { Koles- } \\
\text { terol }\end{array}$ & FSH & LH & E2 & DHEAS & s-test \\
\hline \multirow{2}{*}{ Ferritin } & $\mathbf{r}$ & 0.05 & 0.06 & -0.05 & 0.09 & -0.07 & -0.04 & -0.04 & 0.07 & -0.05 & 0.15 & 0.16 & 0.004 & 0.09 & -0.04 & 0.09 & 0.1 \\
\hline & $p$ & 0.5 & 0.4 & 0.5 & 0.27 & 0.42 & 0.6 & 0.5 & 0.4 & 0.5 & 0.08 & 0.06 & 0.9 & 0.31 & 0.6 & 0.2 & 0.1 \\
\hline \multirow{2}{*}{ CRP } & $\mathbf{r}$ & 0.1 & 0.37 & 0.1 & 0.18 & 0.1 & 0.07 & 0.08 & 0.08 & 0.05 & -0.07 & 0.004 & 0.04 & 0.08 & 0.15 & 0.06 & 0.05 \\
\hline & $p$ & 0.2 & $<0.0001$ & 0.09 & 0.04 & 0.2 & 0.4 & 0.3 & 0.3 & 0.5 & 0.3 & 0.9 & 0.6 & 0.3 & 0.08 & 0.4 & 0.5 \\
\hline
\end{tabular}

VKi: Vücut kitle indeksi; WHR: Bel kalça oranı; FGS: Ferriman-Gallway skoru; AKŞ: Açlık kan şekeri; HOMA-IR: Homeostasis model assessment of insulin resistance; TG: Trigliserid; HDL: Yüksek dansiteli lipoprotein; LDL: Düşük dansiteli lipoprotein FSH: Folikul stimulan hormon; LH: Luteinizan hormon; E2: Estradiol; DHEA-S: Dehidroepiandrostenodion sülfat; s-test: serbest testesteron; CRP: C-reaktif protein.

*Spearman veya Pearson korelasyon analizi kullanıımıştr.

Tablo 3: Serum ferritin ve CRP düzeylerinin kardiyovaskuler hastalık gelişiminde prediktif etkisi.

\begin{tabular}{|c|l|c|c|c|c|c|c|}
\hline & & & $\beta$ & p değeri & OR & \multicolumn{2}{|c|}{$\mathbf{9 5 \%}$ Cl for OR } \\
\hline \multirow{2}{*}{ Tüm grup } & CRP & 0.26 & $\mathbf{0 . 0 0 2}$ & 1.30 & 1.1 & 1.54 \\
\hline \multirow{2}{*}{ PKOS grubu } & Sabit & -1.37 & 0.000 & 0.25 & & \\
\cline { 2 - 7 } & CRP & 0.23 & $\mathbf{0 . 0 3}$ & 1.26 & 1.02 & 1.56 \\
\hline & Sabit & -0.60 & 0.12 & 0.54 & & \\
\hline
\end{tabular}

Kovariatlar: Ferritin, CRP.

CRP: C-reaktif protein; PKOS: Polikistik over sendromu.

*Multivariat lojistik regresyon analizi kullanılmıştır

Tablo 4: Serum ferritin ve CRP düzeylerinin insülin rezistansı gelişiminde prediktif etkisi.

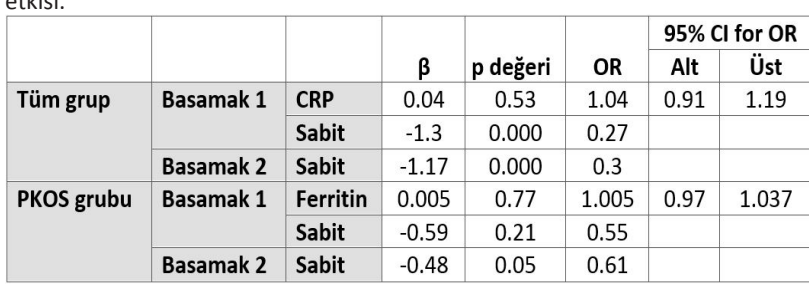

Kovariatlar: Ferritin, CRP.

*Multivariat lojistik regresyon analizi kullanılmıştır

Tablo 5: Obezitenin etkisi dışlandıktan sonra serum ferritin ve CRP düzeylerinin insülin rezistansı gelişiminde prediktif etkisi.

\begin{tabular}{|c|c|c|c|c|c|c|c|}
\hline & & & \multirow[b]{2}{*}{$\beta$} & \multirow[b]{2}{*}{ p değeri } & \multirow[b]{2}{*}{ OR } & \multicolumn{2}{|c|}{$95 \% \mathrm{Cl}$ for $\mathrm{OR}$} \\
\hline & & & & & & Alt & Üst \\
\hline \multirow[t]{2}{*}{ Tüm grup } & & Abdominal obezite & 1.1 & 0.01 & 0.3 & 0.14 & 0.78 \\
\hline & & Sabit & -0.6 & 0.03 & 0.54 & & \\
\hline \multirow[t]{3}{*}{ PKOS } & Basamak 1 & Abdominal obezite & 0.54 & 0.29 & 0.58 & 0.21 & 1.59 \\
\hline & & Sabit & -0.25 & 0.42 & 0.77 & & \\
\hline & Basamak 2 & Sabit & -0.48 & 0.05 & 0.61 & & \\
\hline
\end{tabular}

Kovariatlar: Ferritin, CRP, obezite, abdominal obezite.

*Multivariat lojistik regresyon analizi kullanılmıştr. 
araştırdığımız çalışmamızda PKOS grubunda kontrol grubuna göre ferritin ve CRP düzeylerini daha yüksek bulmuş olsak da iki grup arasında istatistiksel anlamlı fark izlemedik. Çalışmamıza benzer şekilde Ağaçayak ve ark. yaptıkları çalışmalarında, PKOS ve kontrol grubu arasinda inflamasyon belirteçlerinden olan neopterin, interlökin-6, tümör nekrozis faktör- $\alpha$ ve CRP seviyelerini benzer bulmuşlardır (20). PKOS hastalarında neopterin ve CRP düzeylerini kontrol grubuna göre anlamlı yüksek bulan çalışmalar da vardır (19).

PKOS'ta serum ferritin seviyesini araştıran sınırlı çalışma vardır ve çalışmalarda genellikle PKOS'ta serum ferritin seviyesi yüksek bulunmuştur (8). Yüksek ferritin seviyesine sahip kadınlarda PKOS ve hiperandrojenemi riskinin daha yüksek olduğu ve ferritin seviyeleri ile siklus uzunluğu ve androjen yüksekliği arasında pozitif bir ilişki olduğu bulunmuștur (21). Martinez-Garcia ve ark., ferritin yüksekliğine katkıda bulunan kanser, inflamasyon ve infeksiyöz hastalık gibi durumlara sahip olmayan obez ve nonobez PKOS'larda VKİ ve obezite derecesi eşleştirilmiş kontrollere göre serum ferritin düzeyini yüksek bulmuşlardır (12). PKOS ve artmış ferritin düzeylerinin arasındaki ilişkinin nedeni olarak oligomenore nedeni ile olan azalmış kan kaybı ve PKOS hastalarında artmış demir absorpsiyonuna neden olan azalmış hepsidin seviyeleri öne sürülmüştür (22). Ayrıca vücutta ve overde demir birikiminin OS'i arttırarak PKOS'lu kadınlarda gonadal fonksiyonun azalmasına neden olabileceği ve OS'de ve insülin sinyal yolunda etkili olan faktörlerin granuloza hücre disfonksiyonunda görevli olabileceği düşünülmektedir (7). Serum ferritin seviyeleri obeziteden etkilenir, çünkü obezite ve demir metabolizması arasında ilişki tespit edilmiştir (23). Serum ferritin düzeyi normal kilolu PKOS'ta kontrollere göre benzer bulunurken, kilolu ve obez PKOS'ta kontrollere göre yüksek bulunmuştur (15). PKOS'ta ferritin seviyelerini araştıran yukarda belirtilen çalışmalar genelde reproduktif dönem kadınları kapsamakta olup katılımcıların yaş aralığ 1 21-35 yaştır. Çalışmamız ise daha çok adolesan ve genç yaş kadınları kapsamakta ve katılımcıların yaş ortalaması daha genç (ortalama 19 yaş) olup,yaş aralığı da daha dar idi. Sonuçlardaki farklılıklar çalışma gruplarının yaş ortalamasının farklı olmasından veya ilerleyen yaşla beraber belirginleşen obezite, IR ve oligomenorenin kan kaybını belirgin azaltmas1 etkisi ile ferritin ve CRP seviyelerinin yükseliyor olmasından kaynaklanabilir. Çalışma grubumuzun hem obez hem nonobez hastaları içeriyor olması ve çalışma grupları arasında VKI'nin anlamlı farklı olması ve örneklemimizin kısmen küçük olması diğer çalışmalarla sonuçlarımızın farklı çıkmasının bir nedeni olabilir.

Çalışmamızda serum ferritin düzeyinin hem tüm çalışma grubunda hem PKOS grubu içinde antropometrik, hormonal ve biyokimyasal parametreler ile ilişkisini bulamazken; serum CRP düzeyleri VKİ arasında pozitif korelasyon bulduk. Ko ve ark. obeziteden bağımsız olarak artmış demir ile hipertrigliseridemi arasında ilişki bulmuştur (21).
Aynı çalışmada serum ferritin ve total kolesterol düzeyi arasında pozitif korelasyon bulunmuştur (21). PKOS hastalarında yapılan başka bir çalışmada ise, çalışmamıza benzer şekilde, serum ferritin seviyeleri ile CRP, VKİ, WHR ve HOMA-IR arasinda metformin tedavisinden önce veya sonra herhangi bir ilişki bulunmazken, CRP ile VKİ ve IR arasında pozitif korelasyon bulunmuştur (24). Obezlerde, CRP ile abdominal obezite ve IR arasında ilişki bulunmuştur (14). PKOS hastalarında antropometrik ölçümlerin, özellikle WHR'nin, metforminle düzeltilebildiği ve WHR'deki azalma sonucu CRP düzeylerinde düşme olduğu izlenmiştir (15). Nonobez kadınlarda serum ferritin düzeyi ile HOMA-IR indeks arasında bir ilişki tespit edilememiştir (25). Reproduktif dönemdeki kadınlarda ferritin ve hiperandrojenemi arasında ilişki olduğu gösterilmiştir (12). Çalışmamızın adolesan ve genç yaş grubu kadınları kapsaması, diğer çalışmaların ise daha çok reproduktif dönemi kapsaması farklı sonuçların nedeni olabilir.

Serum ferritin ve CRP düzeylerinin KVH gelişim riski üzerine prediktif etkisini incelediğimizde, çalışmamızda, serum CRP düzeylerinin hem tüm çalışma gubu içinde hem de PKOS grubu içinde KVH gelişim riski üzerine pozitif prediktif etkisini izlerken, serum ferritin düzeylerinin $\mathrm{KVH}$ gelişimi üzerine herhangi bir etkisini izlemedik. Kronik inflamasyonun PKOS hastalarında $\mathrm{KVH}$ riskini arttırdığ 1 gösterilmiştir (16). Nonobez katılımcılar1 içeren diğer bir çalışmamızda serum neopterin, CRP düzeylerinin ve tam kan sayımı inflamatuar belirteçlerinin hiç birinin ne PKOS grubunda ve ne de tüm grupta KVH gelişim riski üzerine herhangi bir etkisini izlemedik (19). Artmış serum ferritin düzeylerinin nonobezlerde metabolik sendromun bir parçası olabileceği gösterilmiştir (25). Ferritinin metabolik bozukluğun iyi bir indikatörü olduğu ve serum ferritin düzeyini ölçmenin özellikle reproduktif yaş kadınlarda $\mathrm{KVH}$ riskini değerlendirmede faydalı olabileceği düşünülmektedir (21). Yapılan çalışmalarda $\mathrm{KVH}$ gelişim için risk faktörlerinin farklı alınması ve yine çalışmamıza katılan katılımcıların yaş ortalamasının daha genç grubu içermesi çalışmalar arasındaki farklı sonuçların nedeni olabilir.

Çalışmamızda IR gelişimi üzerine ferritin ve CRP'nin herhangi bir etkisi izlenmezken obezite ve abdominal obezite için düzeltilme yapıldıktan sonra tüm çalışma grubunda abdominal obezitenin IR gelişimi üzerine pozitif prediktif etkisini izledik. Genel populasyonda artmış vücut demir depoları ve metabolik bozukluklar (anormal glikoz tolerans testi, diabet, obezite, IR, hipertansiyon) arasında ilişki bulunmuştur $(8,11,12)$. PKOS'lu kadınları içeren bir çalışmada ise serum ferritin düzeyinin artması obezite, IR ve oligomenore ciddiyeti ile ilişkili bulunmuştur (7). IR'nin obezite ve özellikle abdominal obeziteden etkilenmesi nedeniyle obez ve nonobez grubu ayrı ayrı inceleyen çalışmalar mevcuttur. Nonobez PKOS hastalarında abdominal obezite için düzeltilme yapıldıktan sonra serum CRP düzeyinin IR için prediktif olmadığı bulunmuştur (19). 
Obez kadınlarda yüksek serum ferritin düzeyi IR ve metabolik durumlarla ilişkili bulunurken bu ilişki nonobezlerde izlenmemiştir (21). Obez ve nonobezlerde ferritin ve IR'nin farklı ilişkisi obez ve nonobezlerde artmış serum ferritinin IR ile etkileşiminin farklı mekanizmalarla olabileceğini düşündürmüştür. Ferna'ndez-Real ve ark. demir ve glikoz metabolizması arasında bilateral bir ilișki olduğunu, demirin insülin sekresyonu ve sensitivitesini insülinin de demir metabolizmasını etkilediğini söylemektedir (6). Biz çalışmamızda katılımcıları obez ve nonobez diye gruplara ayırmadığımız için ferritin ve CRP'nin IR üzerine etkisini araştırırken regresyon analizi ile obezite ve abdominal obezitenin etkisini dışlayıp daha net bir sonuç elde etmek istedik.

Örneklem sayısının küçük olması ve çalışma grubumuzun bazı fizyolojik durumların PKOS'un klinik bulguları ile üst üste binebildiği adolesan ve genç yaş grubunu içermesi çalışmamızın major limitasyonudur. Bu durumdan kaynaklanabilecek sorunları en aza indirmeye çalışmak için menarş başlayalı en az 3 yıl geçen hastaları çalışmamıza almış olsak da oligomenoresi 2 yildan fazla devam etmeyen ve hiperandrojeneminin klinik veya biyokimyasal bulguları olan adolesanlarda PKOS tanısı koyarken dikkatli olunmalıdır. Serum ferritin düzeyi yaş ve etnisiteye göre farklılık gösterdiği için çalışmamıza katılan tüm hastalar aynı coğrafik bölgeden ve dar bir yaş aralığında seçildi. Diğer yandan katılımc1ların yaş aralığının çok dar olması sonuçlarımızın genelleştirilmesini de kısıtlayabilir. Çalışmamızın diğer bir limitasyonu grupların VKİ ile eşleştirilmemiş olmasıydı çünkü serum ferritin düzeyleri VKI'den etkilenebilmektedir. Multilojistik regresyon analiziyle obezite ve abdominal obezitenin etkisini dişlayarak bu durumdan kaynaklanabilecek biasları en aza indirmeye çalıştık.

Sonuç olarak, erken erişkinlik döneminde serum ferritin ve CRP düzeylerinin PKOS gelişiminde etkisi görünmemektedir. Serum CRP düzeyleri hem PKOS grubunda hem genel populasyonda KVH gelişim riskini öngörmede bir belirteç olabilir. Ferritin ve CRP'nin PKOS'un etyopatogenezindeki rolünü ve PKOS'un uzun dönem morbiditelerinin gelişimindeki etkisini araştırmak için iyi dizayn edilmiş büyük örneklemli prospektif çalışmalara ihtiyaç vardir.

\section{$K \boldsymbol{A} Y \boldsymbol{N} \boldsymbol{A} \boldsymbol{K} L \boldsymbol{A} R$}

1. Lauritsen MP, Bentzen JG, Pinborg A, Loft A, Forman JL, Thuesen LL, Cohen A, Hougaard DM, Nyboe Andersen A. The prevalence of polycystic ovary syndrome in a normal population according to the Rotterdam criteria versus revised criteria including anti-Mullerian hormone. Hum Reprod. 2014;29(4):791-801.

2. Li R, Zhang $O$, Yang D, Li S, Lu S, Wu X, Wei Z, Song X, Wang X, Fu S, Lin J, Zhu Y, Jiang Y, Feng HL, Qiao J. Prevalence of polycystic ovary syndrome in women in China: a large community-based study. Hum Reprod. 2013;28(9):2562-9.

3. Hyderali BN, Mala K. Oxidative stress and cardiovascular complications in polycystic ovarian syndrome. Eur J Obstet Gynecol Reprod Biol. 2015;191:15-22.

4. Turan V, Sezer ED, Zeybek B, Sendag F. Infertility and the presence of insulin resistance are associated with increased oxidative stress in young, non-obese Turkish women with polycystic ovary syndrome. J Pediatr Adolesc Gynecol. 2015;28(2):119-23.

5. Ong SY, Nicoll AJ, Delatycki MB. How should hyperferritinaemia be investigated and managed? Eur J Intern Med. 2016;33:21-7.

6. Fernandez-Real JM, Lopez-Bermejo A, Ricart W. Cross-talk between iron metabolism and diabetes. Diabetes. 2002;51(8):2348-54.

7. Yang JH, Chou CH, Yang WS, Ho HN, Yang YS, Chen MJ. Iron stores and obesity are negatively associated with ovarian volume and anti-Mullerian hormone levels in women with polycystic ovary syndrome. Taiwan J Obstet Gynecol. 2015;54(6):686-92.

8. Escobar-Morreale HF, Luque-Ramirez M, Alvarez-Blasco F, Botella-Carretero JI, Sancho J, San Millan JL. Body iron stores are increased in overweight and obese women with polycystic ovary syndrome. Diabetes Care. 2005;28(8):2042-4.

9. Escobar-Morreale HF, Luque-Ramirez M, San Millan JL. The molecular-genetic basis of functional hyperandrogenism and the polycystic ovary syndrome. Endocr Rev. 2005;26(2):251-82.

10. Fernandez-Real JM, Ricart W. Insulin resistance and chronic cardiovascular inflammatory syndrome. Endocr Rev. 2003;24(3):278-301.

11. Kim CH, Kim HK, Bae SJ, Park JY, Lee KU. Association of elevated serum ferritin concentration with insulin resistance and impaired glucose metabolism in Korean men and women. Metabolism. 2011;60(3):414-20.

12. Martinez-Garcia MA, Luque-Ramirez M, San-Millan JL, Escobar-Morreale HF. Body iron stores and glucose intolerance in premenopausal women: role of hyperandrogenism, insulin resistance, and genomic variants related to inflammation, oxidative stress, and iron metabolism. Diabetes Care. 2009;32(8):1525-30.

13. Escobar-Morreale HF, San Millan JL. Abdominal adiposity and the polycystic ovary syndrome. Trends Endocrinol Metab. 2007;18(7):266-72.

14. Festa A, D'Agostino R, Jr., Tracy RP, Haffner SM, Insulin Resistance Atherosclerosis S. Elevated levels of acute-phase proteins and plasminogen activator inhibitor-1 predict the development of type 2 diabetes: the insulin resistance atherosclerosis study. Diabetes. 2002;51(4):1131-7.

15. Morin-Papunen L, Rautio K, Ruokonen A, Hedberg P, Puukka $M$, Tapanainen JS. Metformin reduces serum C-reactive protein levels in women with polycystic ovary syndrome. J Clin Endocrinol Metab. 2003;88(10):4649-54.

16. Ridker PM, Hennekens CH, Buring JE, Rifai N. C-reactive protein and other markers of inflammation in the prediction of cardiovascular disease in women. N Engl J Med. 2000;342(12):836-43.

17. Fruzzetti F, Perini D, Lazzarini V, Parrini D, Genazzani AR. Hyperandrogenemia influences the prevalence of the metabolic syndrome abnormalities in adolescents with the polycystic ovary syndrome. Gynecol Endocrinol. 2009;25(5):335-43.

18. NCEP. Expert Panel on Blood Cholesterol Levels in Children and Adolescents. National Cholesterol Education Program (NCEP): Highlights of the report of the Expert Panel on Blood Cholesterol Levels in Children and Adolescents. Pediatrics 1992;89(3):495-501.

19. Tola EN, Yalcin SE, Dugan N. The predictive effect of inflammatory markers and lipid accumulation product index on clinical symptoms associated with polycystic ovary syndrome in nonobese adolescents and younger aged women. Eur J Obstet Gynecol Reprod Biol. 2017;214:168-72.

20. Agacayak E, Tunc SY, Sak S, Basaranoglu S, Yuksel H, Turgut A, et al. Levels of Neopterin and other Inflammatory Markers in Obese and Non-Obese Patients with Polycystic Ovary Syndrome. Med Sci Monit. 2015;21:2446-55.

21. Ko PC, Huang SY, Hsieh CH, Hsu MI, Hsu CS. Serum ferritin levels and polycystic ovary syndrome in obese and nonobese women. Taiwan $J$ Obstet Gynecol. 2015;54(4):403-7.

22. Escobar-Morreale HF. Iron metabolism and the polycystic ovary syndrome. Trends Endocrinol Metab. 2012;23(10):509-15.

23. Aigner E, Feldman A, Datz C. Obesity as an emerging risk factor for iron deficiency. Nutrients. 2014;6(9):3587-600.

24. Behradmanesh S, Ranjbar Omrani GH, Ghazanfarpour F, Baradaran A. Effect of metformin on serum ferritin level in women with polycystic ovary syndrome. Iran Red Crescent Med J. 2011 Jul;13(7):487-92.

25. Yoo KD, Ko SH, Park JE, Ahn YB, Yim HW, Lee WC, Park YM. High serum ferritin levels are associated with metabolic risk factors in non-obese Korean young adults: Korean National Health and Nutrition Examination Survey (KNHANES) IV. Clin Endocrinol (Oxf). 2012;77(2):233-40. 